УДК $343.3 / .7$

DOI https://doi.org/10.32837/yuv.v0i1.2089

В. Самотієвич,

кандидат юридичних наук,

доцент кафедри кримінального права та кримінології

Харківського національного університету внутрішніх справ

\title{
ДО ПИТАННЯ ЗАКОНОДАВЧОЇ ТЕХНІКИ КОНСТРУЮВАННЯ КВАЛІФІКОВАНИХ СКЛАДІВ КРИМІНАЛЬНИХ ПРАВОПОРУШЕНЬ У КРИМІНАЛЬНОМУ КОДЕКСІ УКРАЇНИ
}

Кримінальна відповідальність є різновидом юридичної відповідальності та передбачає, серед іншого, застосування певного виду й міри особистих, майнових чи інших обмежень, встановлених кримінальним законом, які завжди мають вимушений характер. Застосування таких обмежень має відбуватися лише за наявності чітко визначених у законі підстав: так, у ч. 1 ст. 2 Кримінального кодексу України (далі - КК України) вказано «Підставою кримінальної відповідальності $€$ вчинення особою суспільно небезпечного діяння, яке містить склад кримінального правопорушення, передбаченого цим Кодексом» [1]. Прийняття рішення про притягнення / не притягнення особи до кримінальної відповідальності залежить від багатьох чинників, одним з яких $є$ правильність розуміння правозастосувачем ознак тих складів кримінальних правопорушень, що містяться в КК України.

Право визнання тих чи інших діянь кримінальними правопорушеннями належить виключно до компетенції Верховної Ради України, яка й здійснює їх криміналізацію, попередньо оцінивши умови життя суспільства та встановивши необхідність віднесення діяння через його високу суспільну небезпечність до числа кримінальних правопорушень. Формалізація таких суспільно-небезпечних діянь в законі здійснюється шля- хом створення законодавчих моделей кримінальних правопорушень, які вмішують найсуттєвіші, найнеобхідніші ознаки відповідних діянь. I тут законодавець має бути максимально чітким та однозначним у викладенні цих ознак, аби забезпечити у майбутньому можливість застосування таких норм до осіб лише у випадках вчинення ними саме тих суспільно небезпечних діянь, які правотворцями були визнані такими, що мають високу суспільну небезпечність.

Правозастосовна ж діяльність свідчить, що часто ознаки окремих складів кримінальних правопорушень сформульовані не достатньо чітко, що ускладнює процес кваліфікації вчинених діянь та призводить до прийняття різними суб'єктами протилежних рішень за подібних обставин вчинення суспільно небезпечних діянь, що, в свою чергу, обумовлює актуальність окресленої проблеми. У даній статті досліджуватимуться окремі недоліки конструювання кваліфікованих складів кримінальних правопорушень та буде здійснено пошук таких способів їх викладення, які б дозволили мінімізувати випадки неоднозначності тлумачення, що і визначаємо за мету нашого дослідження.

Окреслене нами питання має комплексний характер, яке має розглядатися, по-перше, 3 точки зору юридичної техніки, значний вклад 
в розробку якої внесено багатьма вченими, серед яких Антипов B.I., Балабанова Д.О., Вечерова Є. М., Загиней 3.А., Ющик О. І. та ін. Також, слід зауважити на наукові праці, присвячені вивченню ознак, що кваліфікують кримінальне правопорушення, таких вчених як Кругліков Л.Л., Mapiн O.K., Мармура O.3., Ільіна О.В., Наконечна I.M., а також врахувати ті роботи, в яких досліджено проблеми кваліфікації кримінальних правопорушень - Коржанського М.Й., Кузнецова В.В., Навроцького В.О., ін. Досягнення поставленої нами мети вважаємо за можливе саме шляхом дослідження наукових надбань в цих трьох напрямках та аналізу сучасної правозастосовчої практики.

Традиційно кваліфікованим складом кримінального правопорушення називають склад із кваліфікуючими ознаками або обтяжуючими обставинами, а його різновидом - особливо кваліфікований склад, який містить особливо обтяжуючі обставини, що надають кримінальному правопорушенню особливої суспільної небезпечності. У нашій статті ми не будемо розділяти кваліфікований та особливо кваліфікований склади, та застосовуватиме термін «кваліфікований склад» як об'єднуючий.

У чинному КК України основний та кваліфікований склади викладаються в одній статті: основний склад міститься в частині першій, кваліфіковані - в наступних частинах. Проте єдність у викладенні ознак кваліфікованих складів кримінальних правопорушень відсутня: починатися відповідні частини статей Особливої частини КК України можуть по-різному - «те саме діяння...», «ті самі діяння...», «ті самі дії..», «дії, передбачені частиною....», «діяння передбачене частиною...», інколи взагалі кваліфікований склад починається із назви самого кримінального правопорушення. Намагаючись осягнути таку різноманітність й зрозуміти, чим викликана потреба різних формулю- вань та яке змістове навантаження вони мають, B.I. Антипов запропонував виокремити три основні варіанта законодавчої техніки, що використовуються для опису ознак об'єктивної сторони складів кримінального правопорушення [2, с. 36].

До першого варіанту віднесено ті конструкції, диспозиція яких починається 3 назви кримінального правопорушення 3 подальшим викладенням кваліфікуючих ознак, як-то В ч. 2 ст. 121 , ч. $2-5$ ст. 185 , ч. 2,3 ст. 152 КК України. Переважно це ті склади кримінальних правопорушень, диспозиція яких $€$ описовою, а назва складається 3 одного-двох слів - «Вимагання», «Грабіж», «Крадіжка», «Згвалтування», «Шахрайство» та ін. Проте не завжди законодавець вдається до цього прийому. Так, наприклад, у ст. 296 «Хуліганство», ст. 258 «Терористичний акт» для конструювання їх кваліфікованих складів законодавець не використав описаного прийому, розпочавши їх словами «ті самі дії...» та «дії, передбачені...».

Такий підхід вбачається доволі раціональним, адже він дозволяє уникати дублювання змісту основного складу кримінального правопорушення, що міститься в першій частини окремої статті та, відповідно, спрощує редакцію кримінально-правової норми. Та навряд чи такий спосіб можна застосовувати як універсальний при конструюванні будь-яких кваліфікованих складів: по-перше, окремі норми мають досить довгі назви, що призведе до збільшення обсягу норми, а, по-друге, слід пам'ятати й про можливість колізіі між назвами та диспозиціями норм Особливої частини $\mathrm{KK}$ України, як-то, наприклад, у ст. 200 КК України [3, с. 413], що також не сприятиме уникненню розбіжностей при застосуванні такої норми.

Другий вид конструювання кваліфікованого складу кримінального правопорушення передбачає використання 
таких словосполучень, як «те саме діяння», «ті самі діяння», «діяння передбачені частиною..», після яких зазначаються кваліфікуючі ознаки. В кримінальному праві України термін «діяння» традиційно використовують як обов'язкову ознаку об’єктивної сторони, яка $є$ притаманною усім без винятку кримінальним правопорушенням, що має дві форми - дію та бездіяльність. Саме дію і бездіяльність розуміє законодавець в багатьох випадках при формулюванні різних норм, що містяться в Загальній частині КК України, використовуючи термін «діяння», на що прямо вказує в окремих нормах (наприклад у ст. 12 зазначено, що «Кримінальним проступком $є$ передбачене цим Кодексом діяння (дія чи бездіяльність)...», у ст. 15 зазначено, що «Замахом на кримінальне правопорушення $є$ вчинення особою 3 прямим умислом діяння (дії або бездіяльності)..». Подібну вказівку на розуміння діяння, як дії або бездіяльності, можна побачити також, наприклад, у ст.ст. 24, 25, 42 КК України). Натомість, під час конструювання кваліфікованих складів в нормах Особливої частини КK України законодавець не надає чіткої вказівки на кшталт тому, як це ми бачимо в Загальній частині KK України стосовно значення цього терміну. Вважається, що під час формулювання кваліфікованих складів слово «діяння» застосовано законодавцем у значно ширшому сенсі: ним охоплено не лише ознаки об'єктивної сторони у вигляді дії чи бездіяльності, а поняття складу кримінального правопорушення цілком [2, с. 38].

Таким чином, використання назви кримінального правопорушення або застосування поняття «діяння» для формулювання кваліфікованих складів кримінальних правопорушень не повинно викликати труднощів під час кваліфікації, адже обидві конструкції свідчать, що кваліфікованим складом кримінального правопорушення повністю охоплюються ознаки основ- ного складу кримінального правопорушення - ті, що характеризують об'єкт, об'єктивну сторону (в тому числи наслідки в тих складах, де вони $є$ обов'язковою ознакою цих конкретних складів кримінальних правопорушень), суб'єкт та суб'єктивну сторону. Однак детальний аналіз норм чинного кримінального законодавства та практики його застосування демонструє, що це не завжди так, а отже, під час кваліфікації виникають певні сумніви щодо ознак кваліфікованого складу кримінального правопорушення.

Якщо припускати, що «діяння» при конструюванні кваліфікованого складу кримінального правопорушення включає в себе усі ознаки його основного складу, то ч. 2 ст. 194 КК України «Умисне знищення або пошкодження майна» мала б охоплювати ознаки наслідку, закріпленого в ч.1 - заподіяння шкоди у великих розмірах. Натомість правозастосовна практика пішла іншим шляхом. Так, колегією суддів Другої судової палати Касаційного кримінального суду в ухвалі було зазначено, що розмір спричиненої майнової шкоди при кваліфікації випадків умисного знищення чи пошкодження майна шляхом підпалу, вибуху чи іншим загальнонебезпечним способом (ч. 2 ст. $194 \mathrm{KK}$ ) не має правового значення [4].

На користь прийнятого рішення в ухвалі наведено наступні аргументи: 1. Якби для кваліфікації за ч. 2 ст. 194 слід було б встановлювати всі ознаки основного складу кримінального правопорушення, зазначеного в ч. 1 цієї ж статті, то, за умови заподіяння майнової шкоди в особливо великих розмірах, під час кваліфікації за ч. 2 ст. 194 необхідно було б встановити всі ознаки складу, передбаченого ч.1, а саме «спочатку слід встановити великий, а потім ще й особливо великий розмір шкоди».

На нашу думку, в цьому випадку немає ніяких суперечок, адже для кваліфікації за ч. 2 ст. 185 
(«Крадіжка»), у випадку іiі вчинення за попередньою змовою групою осіб, обов'язково слід також з'ясувати, що вартість викраденого майна перевищувала 0,2 неоподаткованих мінімумів доходів громадян. Коли ж крадіжка вчинена у великих розмірах, такі діяння будуть кваліфікуватись за ч. 4 ст. 185 КК України, оскільки кваліфікуюча ознака уточнює, «звужує» одну з ознак основного складу. Зрозуміло, що не слід встановлювати наявність ознак наслідків, передбачених ч. 1 ст. 286 КК України, а саме спричинення потерпілому середньої тяжкості тілесного ушкодження у разі спричинення смерті потерпілого, адже в цьому випадку кваліфікований склад кримінального правопорушення (ч. 2 ст. 296 КК України) в якості кваліфікуючої ознаки містить настання більш тяжкого наслідку, аніж в основному складі, а саме - смерті потерпілого або заподіяння тяжкого тілесного ушкодження. Наступним прикладом $є$ відсутність необхідності встановлювати кількість рослин снотворного маку відповідно до ч. 1 ст. 310 у випадку, коли особа вирощувала їх в кількості, зазначеній у ч. 2.

Таким чином, застосовування в якості кваліфікуючих ознак уточнених / видозмінених / звужених окремих ознак основного складу кримінального правопорушення $€$ традиційним для розробки кваліфікованих складів. А отже, розглянутий нами аргумент на користь того, що кваліфікований склад не повинен включити всіх ознак основного складу кримінального правопорушення через необхідність іхнього начебто «подвійного» встановлення під час кваліфікації кримінального правопорушення не $є$ достатньо доведеним та обгрунтованим.

2. Другий аргумент сформульований наступним чином: «обставина «спричинення загибелі людей чи інші тяжкі наслідки», вкрай обмежує можливості застосування цієї частини (ч. 2. ст. 194 КК України ), зали- шаючи за межами кримінальної відповідальності випадки, коли умисне знищення або пошкодження чужого майна не супроводжувалося заподіянням шкоди у великому розмірі, але спричинило загибель людей чи інші тяжкі наслідки». Це твердження, на нашу думку, більш схоже на припущення, яке не має чіткого формулювання та обгрунтування. У будь-якому разі випадки спричинення загибелі людей та спричинення інших тяжких наслідків можуть розглядатися в межах інших складів кримінальних правопорушень.

3. I останній аргумент на користь того, що ч. 2 ст. 194 не повинна охоплювати ознаки наслідків складу кримінального правопорушення, що містяться в ч.1 ст. 194 КК України (заподіяння шкоди у великих розмірах) полягає в тому, що в даному випадку, на думку суддів, відбувається заміщення обов'язкової характеристики основного складу (наслідку) «що заподіяло шкоду у великих розмірах» обтяжуючими обставинами «те саме діяння, що: вчинене шляхом підпалу, вибуху чи іншим загальнонебезпечним способом; заподіяло майнову шкоду в особливо великих розмірах; спричинило загибель людей; спричинило інші тяжкі наслідки». Суд вказує, що у випадку вчинення такого діяння шляхом підпалу, вибуху чи іншим загальнонебезпечним способом обов'язковою характеристикою $€$ не наслідки, а «загально небезпечний спосіб знищення або пошкодження», оскільки соціальна значущість (суспільна небезпека) способу знищення або пошкодження чужого майна порівняно 3 «шкодою у великих розмірах» є більш вагомою [4].

Розглянутий приклад конструювання кваліфікованого складу кримінального правопорушення та його застосування продемонстрував те, що через нечіткість, неоднозначність його законодавчого закріплення суд у своєму рішенні вдався до самостійного визначення остаточного переліку 
ознак кваліфікованого складу кримінального правопорушення, виключивши ознаки наслідку, передбачені його основним складом.

I останній, третій вид формулювання диспозицій кваліфікованих складів кримінальних правопорушень передбачає використання словосполучень «ті самі діі...», «діï, передбачені частиною(-ами)..». Цей підхід вбачається найбільш неоднозначним, оскільки під дією традиційно в кримінальному праві розуміють активну, свідому, суспільно небезпечну, протиправну поведінку суб'єкта [5, с. 115]. Виходячи із цього, кваліфіковані склади кримінальних правопорушень, об'єктивні ознаки якої сформульовані як «дія...», по-перше, не включають наслідків у випадках, коли основний склад $€$ матеріальним, а отже, не охоплює всіх ознак основного складу; по-друге, взагалі робить абсурдними ті кваліфіковані склади кримінальних правопорушень, які в диспозиції свого основного складу обов'язковою ознакою об'єктивної сторони мають бездіяльність або можуть бути вчинені як шляхом дій так і бездіяльності.

У своїй монографії О.3. Мармуза виділяє ще один вид конструювання кваліфікованих складів кримінальних правопорушень, який полягає у частковому повторенні диспозиції, що регламентує його основний склад [6, с. 94]. Таким прикладом може стати ч. 2 ст. 310 KК України. Однак i тут навряд чи можна говорити про чіткість та однозначність викладення ознак кваліфікованого складу. У початковій редакції ст. 310 «Посів або вирощування снотворного маку чи конопель» друга частина повністю відтворювала зміст частини першої, та містила власне кваліфікуючі ознаки. Не викликало сумнівів, що ч. 2 ст. 310 мала включати усі ознаки, що зазначені в диспозиції основного складу, та, принаймні, одну кваліфікуючу ознаку з ч. 2 ст. 310. Однак після внесення змін основний склад зазначеного кримінального правопо- рушення набув уточнень стосовно предмета кримінального правопорушення, а саме встановлено мінімальні та максимальні межі кількості рослин. Натомість до ч. 2 такі зміни не були внесені. Відтепер буквальне тлумачення ч. 2 ст. 310 не передбачає необхідності встановлювати кількість рослин для кваліфікації діяння за цією частиною, за виключенням, коли кваліфікація за ч. 2 здійснюється за останньою з альтернативних кваліфікуючих ознак - «незаконне вирощування снотворного маку в кількості п'ятисот і більше рослин чи конопель у кількості п'ятдесят і більше рослин». Проте аналіз винесених обвинувальних вироків за ч. 2 ст. 310 свідчить, що правозастосовна практика іде шляхом обов'язкового встановлення відповідного предмету у розмірі, зазначеному в ч. 1 ст. 310 , вдаючись тим самим до поширювального тлумачення закону.

Розподіливши формально підходи у конструюванні кваліфікованих складів кримінальних правопорушень, бачимо, що жоден з них не дає можливості чітко та однозначно встановлювати ознаки кваліфікованого складу кримінального правопорушення з огляду на обрану законодавчу конструкцію його закріплення. Часто незрозумілим залишається те, які саме ознаки, притаманні основному складу кримінального правопорушення, мають охоплюватись кваліфікованими складами кримінальних правопорушень. На наш погляд, виділені чотири підходи конструювання кваліфікованих складів кримінальних правопорушень, які зустрічаються в чинному КK України, застосовуються законодавцем хаотично. Особливо наглядно це проявляється в тих статтях Кримінального кодексу України, в яких міститься декілька кваліфікуючих ознак, сформульованих із застосуванням різних конструкції, які при цьому не несуть різного змістовного навантаження, наприклад у ст.ст. 135, 298 КК України ч. 2 роз- 
починається словами « ті самі дії...», а ч. 3 - «діяння, передбачені...»; у ст.ст. 402, 408 комбінуються два підходи - використання назви кримінального правопорушення та вказівки на «діяння, передбачене...» або «те саме діяння...».

Підсумовуючи аналіз основних підходів застосування законодавчої техніки для конструювання кваліфікованих складів кримінальних правопорушень, бачимо, що всі вони сприяють досягненню лише однієї мети - стислому викладенню кримінально-правової норми, проте не дозволяють досягти зрозумілості відповідних норм, що й породжує неоднозначність їх тлумачення та розбіжності у застосуванні.

Вирішення виявленої проблеми має полягати в мінімізації способів викладення кваліфікуючого складу кримінального правопорушення. Саме термінологічна єдність має спростити процес застосування чинних норм закону про кримінальну відповідальність. Доволі раціональний підхід викладено у своїй роботі О.3 Мармузою, де запропоновано використовувати замість наявних чотирьох видів конструювання кваліфікованих складів кримінального правопорушення, один - «таке саме кримінальне правопорушення...», або «кримінальне правопорушення, передбачене частинами....».

У тих випадках, коли законодавець вважатиме за необхідне вилучити або зробити необов'язковими окремі ознаки основного складу кримінального правопорушення, які за загальним правилом мають охоплюватися кваліфікованим складом (як-то ознаки наслідку, розмір предмета і т. ін), про це має буде зроблена відповідна примітка в цій же статті KK України. В усіх інших випадках вважати неприпустимим кваліфікацію діяння за тією частиною статті, що містить ознаки, які кваліфікують кримінальне правопорушення, без встановлення усіх ознак основного складу цього кримінального правопорушення (за винятком тих випадків, коли кваліфікуючі ознаки звужують / деталізують ознаки основного складу кримінального правопорушення).

Статтю присвячено аналізу конструювання кваліфікованих складів кримінальних правопорушень в чинному КK України та вивченню підходів їх тлумачення правозастосувачами.

У статті підкреслено, що законодавецьь не має єдиного підходу у конструюванні кваліфікованих складів кримінальних правопорушень. Відмічено, шо в чинному КК України використовуються чотири основні прийоми законодавчої техніки конструювання кваліфікованих складів, проте мета застосування того чи іншого прийому не є чітко визначеною. У результаті аналізу кожного виду конструкиії наголошено на існуванні низки розбіжностей між буквальним значенням кримінально-правових норм того чи іншого виду та практикою іх застосування.

3’ясовано, шо питання необхідності врахування усіх без винятку ознак кримінального правопорушення основного складу під час притягнення особи до кримінальної відповідальності, за умови наявності в скоєному нею діянні ознак кваліфікованого складу кримінального правопорушення, вирішується неоднозначно.

У переважній більшості кваліфікація діянь за кваліфікованим складом кримінального правопорушення здійснюеться за умови встановлення усіх ознак основного складу кримінального правопорушення та, власне, кваліфікуючих. Проте трапляються випадки, коли правозастосовна практика не враховуе окремих ознак основного складу кримінального правопорушення, однак за наявності ознак, що його кваліфікують, вважае за можливе 
притягти особу до кримінальної відповідальності.

Зустрічаються й протилежні приклади, коли буквальне тлумачення кваліфікованих складів кримінальних правопорушень не вимагає обов'язкового встановлення окремих ознак основного складу, проте суб'єкти застосування таких норм в якості обов'язкових ознак встановлюють ті, щз буквально не охоплені конструкцүією кваліфікованого складу.

Відсутність достатньої чіткості у формулюванні кваліфікованих складів призводить до прийняття різними суб'єктами протилежних рішень за подібних обставин вчинення суспільно небезпечних діянь. Уникненню неоднозначності тлумачення кваліфікованих складів кримінальних правопорушень сприятиме, по-перше, використання єдиного прийому законодавчого закріплення кваліфікованих складів, а також дотримання єдиного підходу у застосуванні цих норм, а саме ознаки кваліфікованого складу кримінального правопорушення мають охоплювати усі ознаки його основного складу, окрім випадків, які повинні бути безпосередньо передбачені в законі.

Ключові слова: кваліфікований склад кримінального правопорушення, ознаки складу кримінального правопорушення, законодавча техніка, кримінально-правова кваліфікація.

Samotiievych V. To the issue of qualified corpus delicti construction legislative technique in the Criminal Code of Ukraine

This article is devoted to the construction analysis of qualified corpus delicti in the current Criminal Code of Ukraine and the study of their practical application.

It's emphasized that the legislator does not have a single approach in the construction of qualified criminal offenses. Four basic techniques used in the criminal legislation were considered, the content of each of them was researched. As a result of this work, it is emphasized that there are a number of differences between the literal meaning of each construction and their practical application.

The problem of qualified criminal offenses mandatory features range establishing remains widespread.

In the vast majority of cases, the qualification of acts according to the qualified corpus delicti is carried out under the condition of all main corpus delicti features establishing and qualifying ones. However, there are cases when law enforcement practice does not take into account certain features of the main elements of a criminal offense, but in the presence of signs that qualify it, makes it possible to bring a person to justice.

There are cases when the literal interpretation of qualified corpus delicti does not require the mandatory establishment of certain features of the main composition, however, in practice, such features are mandatory.

The lack of sufficient clarity in the qualified corpus delicti formulation leads to the adoption of different decisions by different subjects in similar circumstances of crimes committing. To avoid these differences in the interpretation of qualified criminal offenses it's necessary to use a single method of qualified offenses legislative enshrinement, as well as to use a single approach in the application of these rules, namely, the characteristics of the qualified criminal offense should cover all features, except that certain situations described in law.

Key words: qualified corpus delicti, corpus delicti criminal offense signs, legislative technique, criminal-legal qualification. 


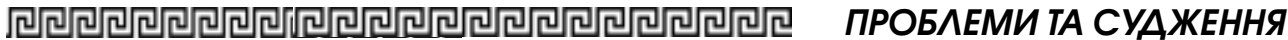

\section{Література}

1. Кримінальний кодекс України : Закон України від 5 квітня 2001 р. № 2341-III / Верховна Рада України. URL: https:// zakon.rada.gov.ua/laws/show/2341-14 (дата звернення: 30.03.2020).

2. Антипов B.I., Диспозиції статей кримінального кодексу України з кваліфікованими складами злочинів потребують корегування. Міжнародний юридичний вісник: актуальні проблеми сучасності (теорія та практика). 2017. Bun. 1(5). C. 34-41.

3. Навроцький В. О. Основи кримінально-правової кваліфікащії: навч. посіб. Київ : Юрінком Інтер, 2006. 704 с.
4. Ухвала Верховного суду від 27.03.2019 у справі № 1-8/2012 провадження № 51-1581км18. URL: http: / / reyestr.court.gov.ua / Review / 80889416 (дата звернення: 06.12.2020).

5. Кримінальне право України. Загальна частина: навчальний підручник / Ю.В. Баулін та ін. ; за заг. ред. В.В. Сташиса, В.Я. Тація. Харків, 2010. $456 \mathrm{c}$

6. Мармуза О.3. Ознакки, що кваліфікують злочин: монографія. Львів : Львівський державний університет внутрішнix справ, 2019. 280 c. 